Acta vet. scand. $1961,2,281-299$.

From the State Veterinary Medical Institute, Stockholm, Sweden.

\title{
HAEMORRHAGIC PNEUMONIA IN MINK CAUSED BY HERELLEA (SYN. DIPLOCOCCUS MUCOSUS, B5W, BACTERIUM ANITRATUM)
}

By

\author{
I. Grabell and K. G. Nyström
}

Pneumonia in mink has been noticed in connection with several different types of infection. In Denmark Knox (20) and in the United States Farrel (13) have observed acute haemorrhagic purulent bronchopneumonia in cases of Pseudomonas aeruginosa septicaemia. The animals suddenly fell ill and mortality was very high. The outbreak was caused by feed and water contamination.

According to Hoff and Woxholtt (17) pneumococcal infection may cause septicaemia with catarrhal-purulent bronchopneumonia. In the case described, the infection occurred after the animals had been fed meat from a calf that had died in pneumococcal septicaemia.

Momberg-Jørgensen (28) has described an acute haemorrhagic-purulent bronchopneumonia with septicaemia caused by Staphylococcus albus in mink.

According to Momberg-Jørgensen (29) and Pridham and Belcher (30) a toxoplasma may also cause pneumonia in mink. A double infection with distemper virus has often been met with. The lungs have been hyperaemic and oedematous with multiple small necroses in the parenchyma. In a case reported by Momberg-Jørgensen (29) diffuse consolidation of the lungs was found. Histological examination showed toxoplasma in the pulmonary parenchyma.

According to Momberg-J $\phi r g e n s e n$ (27) and Garry-Andersson (14) it is usually the virus infection alone that causes the death 
of the animal, contrary to the case in dogs and foxes, and pneumonic pulmonary changes have not been noticed.

Experience gained at this institution speaks in favour of the contrary, Kull (21). Upon examination of the lungs in connection with distemper, the lungs have not seldom shown macroscopically diffuse consolidation and been the site of acute purulent bronchopneumonia. In a few cases, so-called alveolar cell pneumonia has been present. Bacteriologic examination has not, as a rule, revealed any specific infection in these cases.

\section{MATERIAL}

In October, 1959, 4 mink were sent in from a mink farm for autopsy. The animals had been found dead in their cages one morning without the owner having noticed any previous signs of disease. The four dead mink were found in different cages of the mink farm and had not had any contact with each other. The animals were fed a porridgelike mixture ordinarily used, consisting mainly of fish entrails, slaughter waste, and cereals. No alteration had lately taken place concerning the feeding. According to the owner, similar deaths had occurred later in October. In November still another mink was sent in for autopsy. A sample of feed was also sent for bacteriological examination. The owner stated that no special type of mink was predisposed to the disease. Nor did age play a rôle.

\section{PATHOLOGICO-ANATOMICAL EXAMINATIONS}

\section{Gross examination}

All the five mink, one whelp and four full-grown animals, showed similar changes.

An average state of nourishment was seen. The lymph nodes were hyperaemic. In three of the animals the size of the spleen was normal, while in the other two it was slightly enlarged. All the cases showed enlarged lungs that were hyperaemic and consolidated (Fig. 1). In the trachea and the bronchi haemorrhagic, filamentous and mucous exudate was found. Only in minor areas, the lung parenchyma was emphysematous. The pleural cavities showed small amounts of haemorrhagic, filamentous, mucous exudate. The pleura was covered with fine fibrinous strands and revealed petechiae. The stomach and intestines contained a small amount of dark mucus. The liver and kidneys were hyperaemic. 


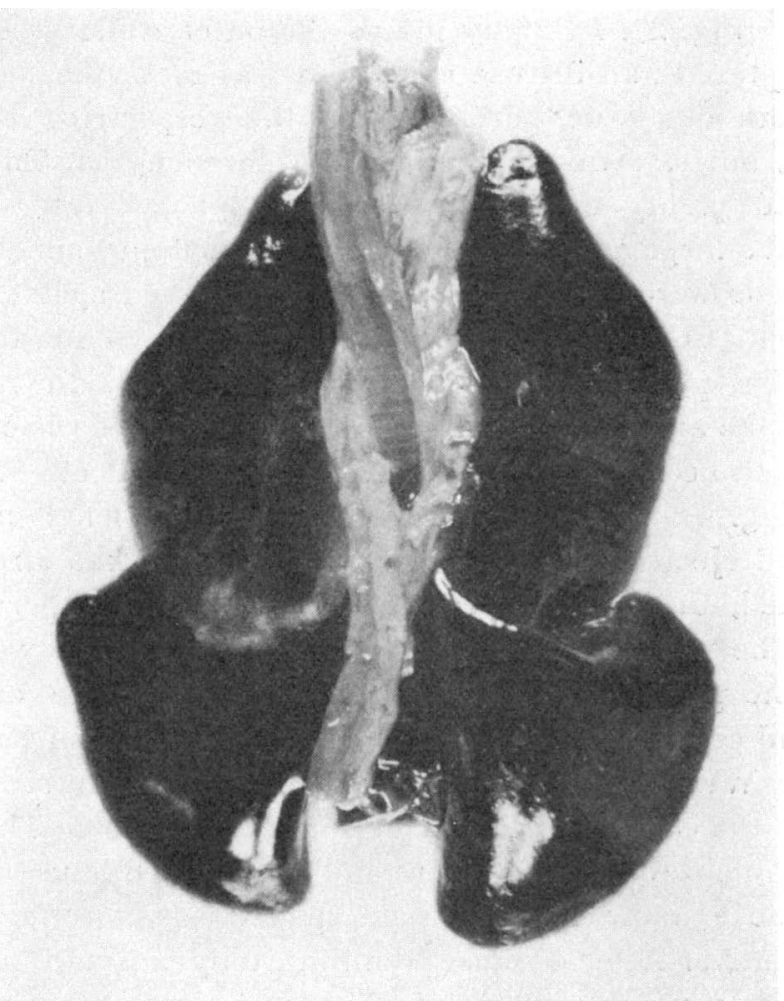

F i g. 1. 0 6151/59. Lungs of mink. Spontaneous case. The lungs are enlarged, extremely hyperaemic and consolidated.

Histopathologic Examinations

Examination of smears from the trachea and urinary bladder concerning the occurrence of distemper inclusions gave a negative result in all the animals.

Microscopically the lungs revealed the same findings on the whole. The parenchyma was extremely hyperaemic and the site of extensive haemorrhages. The lung capillaries were markedly dilated and filled with blood. The haemorrhages were above all localised perivascularly and peribroncially. The alveoli too contained ample amounts of erythrocytes in certain areas.

In some parts the haemorrhages were so extensive that the structure of the lung had disappeared. The vascular endothelium in most of the vessels was swollen and the site of proliferation. The perivascular, peribronchial, and subpleural spaces were dilatated and filled with exudate containing ample amounts of 
bacteria (Fig. 2). In many places the outer walls of the spaces were ruptured and diffuse exudation was met with, not only in the layers of tissue pertaining to the respective vessels and bronchi, but also in the surrounding parenchyma. The exudate contained plenty of erythrocytes and phagocytes which had attracted a large number of bacteria to its cytoplasma. The nuclei of the cells were half-moon-shaped and pressed against the wall of the cell (Fig. 3). In the adjacent lung parenchyma infiltration of similar phagocytes were frequently found. In most lung sections the alveoli were filled with exudate rich in bacteria. The exudate also contained ejected alveolar epithelial cells and phagocytes (Fig. 4 and 5). The bronchi contained plenty of erythrocytes and ejected bronchial epithelial cells. As has already been mentioned, diffuse exudation was found in the peribronchial spaces, the walls of which had partly ruptured and were necrotized. The pleura was covered with ample amounts of erythrocytes and cells. The exudate also contained plenty of bacteria.

After Weigert's fibrin staining, a few fine fibrin strands were found in the exudate of the tissue spaces and alveoli. The exudate in the bronchi was PAS-positive and was stained blue with Alcian blue. The exudate in the tissue spaces was, on the contrary, PAS-negative. After oxidase staining, only a small number of leukocytes were demonstrated. The majority of the phagocytes found were consequently most likely histiocytes.

After staining with methylene blue, masses of bacteria were noticed partly freely in the peribronchial and perivascular tissue and partly phagocytized in macrophages. Also the exudate in the bronchi and alveoli contained great amounts of bacteria.

The liver was hyperaemic and three mink showed slightly fatty liver cells. The kidneys were also hyperaemic and in all the animals slightly fatty changes of the tubular epithelium were seen. Two animals showed a slightly fatty myocardium and body musculature. Histological examination of the brain was carried out in three animals with a negative result in all cases. In one mink there was a slight plasmacytosis with infiltration of plasma cells into the spleen, body lymph nodes, liver, kidneys, and myocardium.

\section{BACTERIOLOGICAL EXAMINATION}

The bacteriological examination comprised parts of the liver, spleen, and lungs from five mink examined post mortem and 


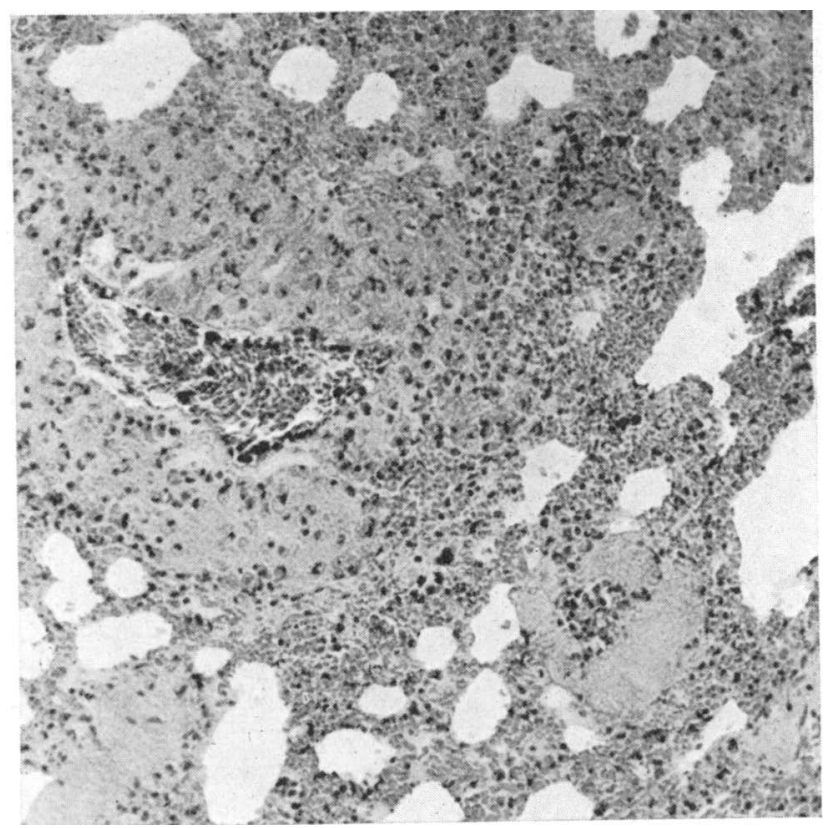

F i g. 2. $05672 / 59$. Lung of mink. Spontaneous case. The adventitial spaces are extremely dilated and filled with inflammatory exudate. The vascular endothelium is slightly swollen tending to proliferate. Cf. Fig. 3. Haematoxylin-eosin, $150 \times$.

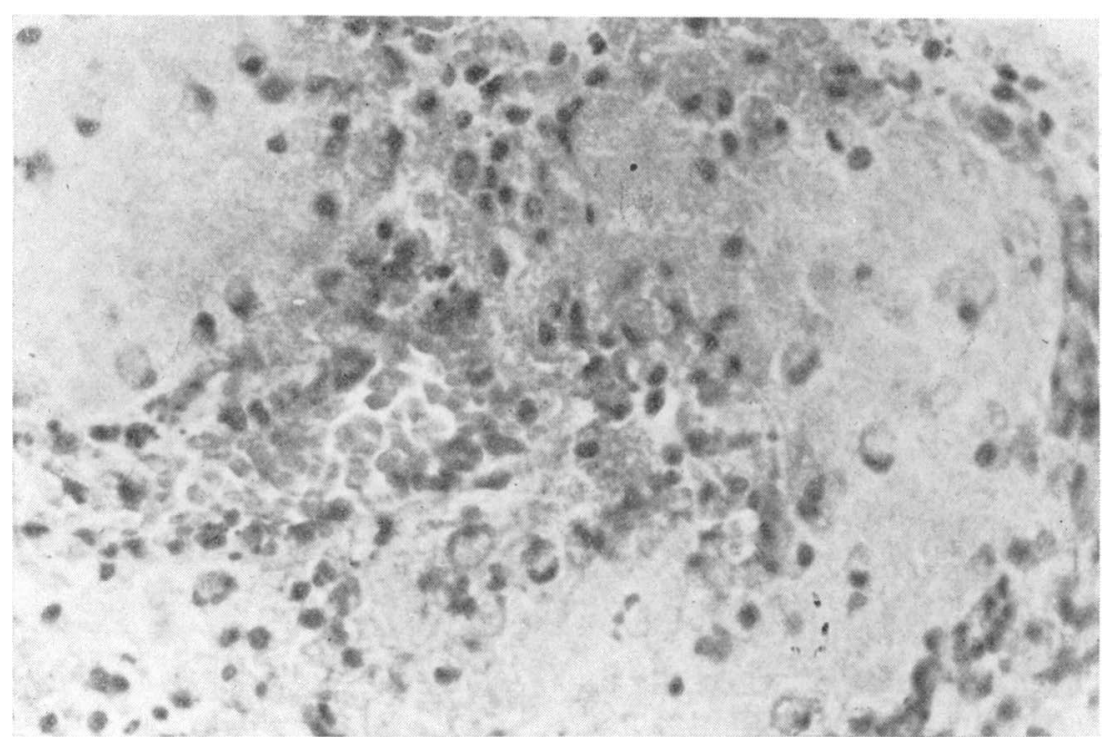

F i g. 3. $05672 / 59$. Lung of mink. Spontaneous case. In the extremely dilated spaces around the pulmonary vein exudate containing abundant amount of bacteria and phagocytizing RE cells. The vascular endothelium is swollen. 


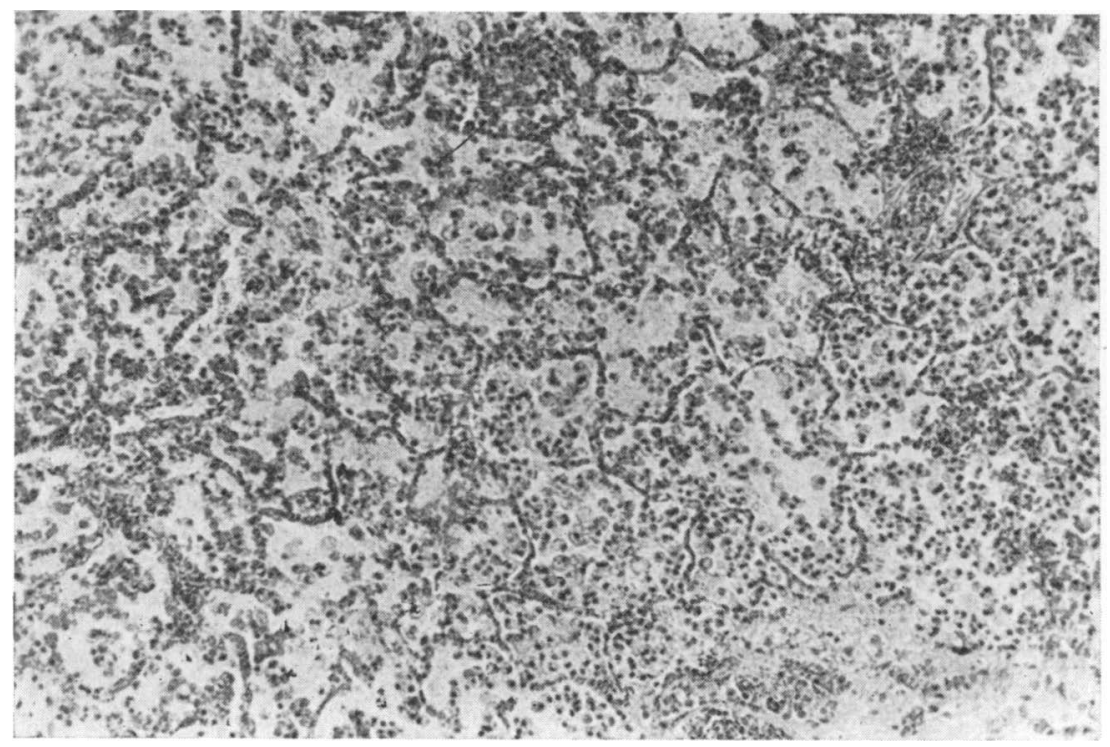

Fi g. 4. $05673 / 59$. Lung of mink. Spontaneous case. The alveoli are filled with ejected epithelial cells, phagocytes and bacteria but show hardly any leukocytes. Cf. Fig. 5. Haematoxylin-eosin, $130 \times$.

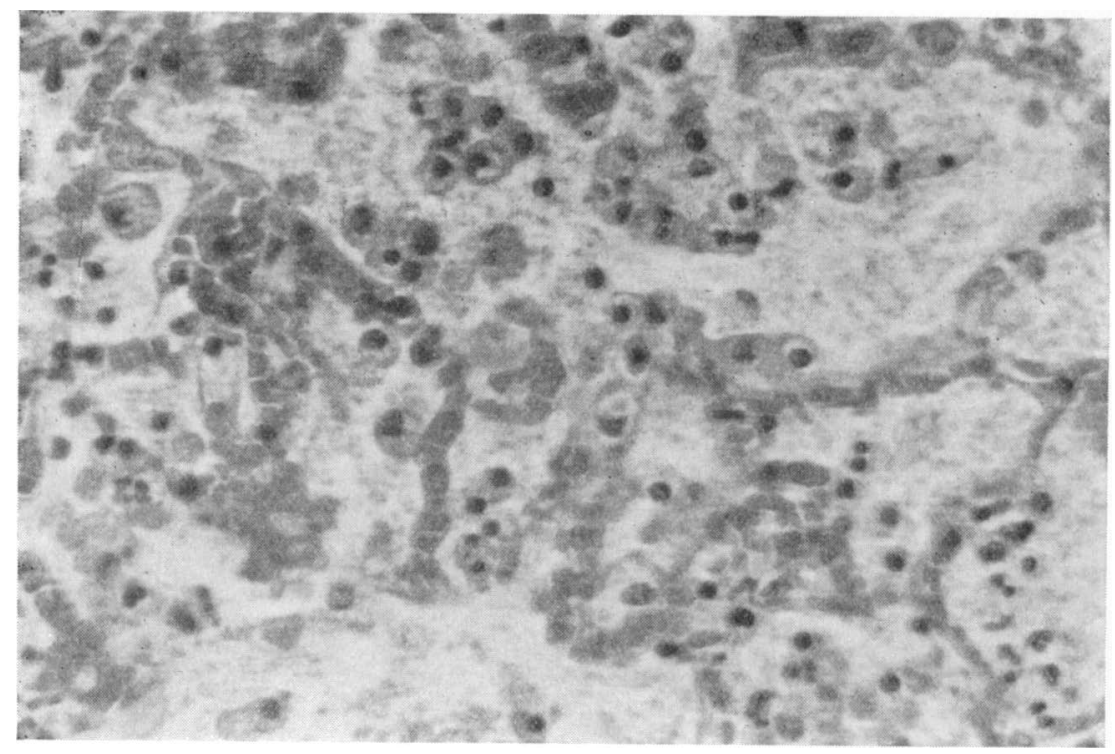

F i g. 5. $05673 / 59$. Lung of mink. Same case as in Fig. 4 in greater magnification. For text see Fig. 4. Haematoxylin-eosin, $440 \times$. 
besides a feed sample from the farm. In the primary culture from the feed sample as well as from the organs of the animals pure cultures of round, convex, greyish, mucoid colonies were found, the surface of which was smooth and glistening and of a viscous consistency.

\section{Morphology}

Microscopically, these primary cultures consisted of pleomorphic, short, straight rods between 1.3 and $1.9 \mu$ long and between 0.6 and $1.3 \mu$ broad, the ends of which were rounded. Under laboratory conditions the diplococcal forms dominated in smears from colonies grown on solid media, but coccoid as well as rod-shaped forms were found in smears from liquid media. The bacteria were non-motile. Neither flagella nore spores could be demonstrated. The occurrence of capsules have been proved in preparations stained with India ink. In smears from solid media the microbe was primarily Gram-labile, under laboratory conditions Gram-negative, in direct smears from animal organs Gram-positive (Fig. 6). Metachromatic granula were demonstrable using Neisser's staining method and the microbe was not acid-fast.

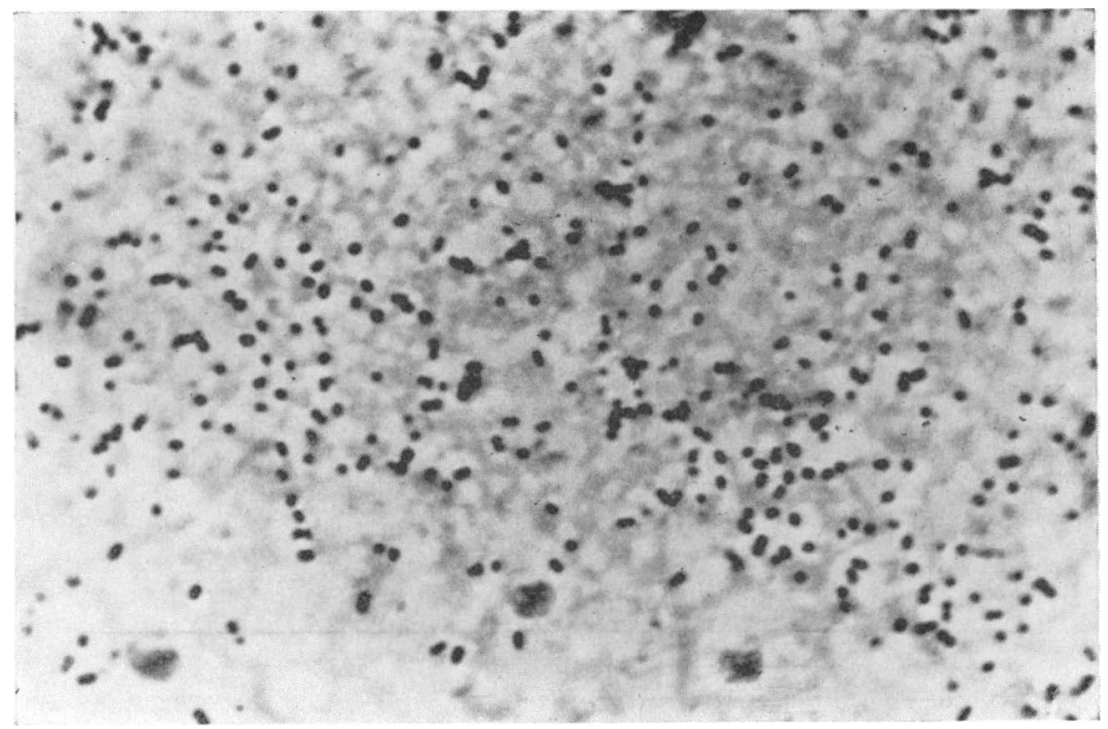

Fig. 6. Smear from liver of an artifically infected mouse. 
Staining methods used are described in Merchant and Packer (26) : 1. Gram. 2. alkaline methylene blue. 3. carbol fuchsin. 4. Hansen's method for spores. 5. Casares-Gil's method for flagella. 6. Hiss's method for capsules. 7. Neisser's method for metachromatic granules. 8. Ziehl-Neelsen.

Hallman (16) : India ink.

\section{Biology}

Surface Colonies on Solid Media. After 2 days of incubation, the surface colonies were circular, about 3 to $5 \mathrm{~mm}$. in diameter, convex, showing an amorphous structure, smooth with an even edge, greyish, opaque of a viscous consistency, and could easily be emulsified in water to a homogenous suspension (Fig. 7). The microbe grew out on Mac Conkey's agar and on SS agar, but not on desoxycholate citrate agar.

The following solid media have been used for the examination: meat extract agar, horse serum agar, blood agar (10-per-cent horse or sheep blood), bromocresol-purple-lactose agar, chocolate agar, desoxycholate citrate agar, Mac Conkey's agar, SS Agar, Dorset's egg medium, potato medium. Compositions, see Merchant and Packer (26), Winkle (39) and Simmons and Gentzkow (34).

Growth in Stroke Culture. Abundant, confluent, spreading growth similar to that described of surface colonies. Meat extract agar medium was used.

Growth in Shake Culture. Growth only on the surface of the medium, which was glucose meat extract agar.

Growth in Fluid Medium. Meat infusion broth was used as medium. After incubation at $37^{\circ} \mathrm{C}$. for 18 hours abundant growth was obtained without turbidity. On the other hand, surface growth was seen in the form of a thick surface pellicle which disintigrated into large-flaky turbidity upon shaking. Slightly stale odour.

Growth in Blood Agar. The appearance of the surface colonies has been described previously. Haemolysis has not been proved in 10-per-cent horse- or sheep-blood agar.

\section{Resistance.}

Heat. Determination of the thermal death time.

Meat-broth culture incubated at $37^{\circ} \mathrm{C}$ for 18 hours was enclosed in capillary tubes, which had been lowered into water baths of different temperatures for 10,30 , and $60 \mathrm{~min}$., respecti- 


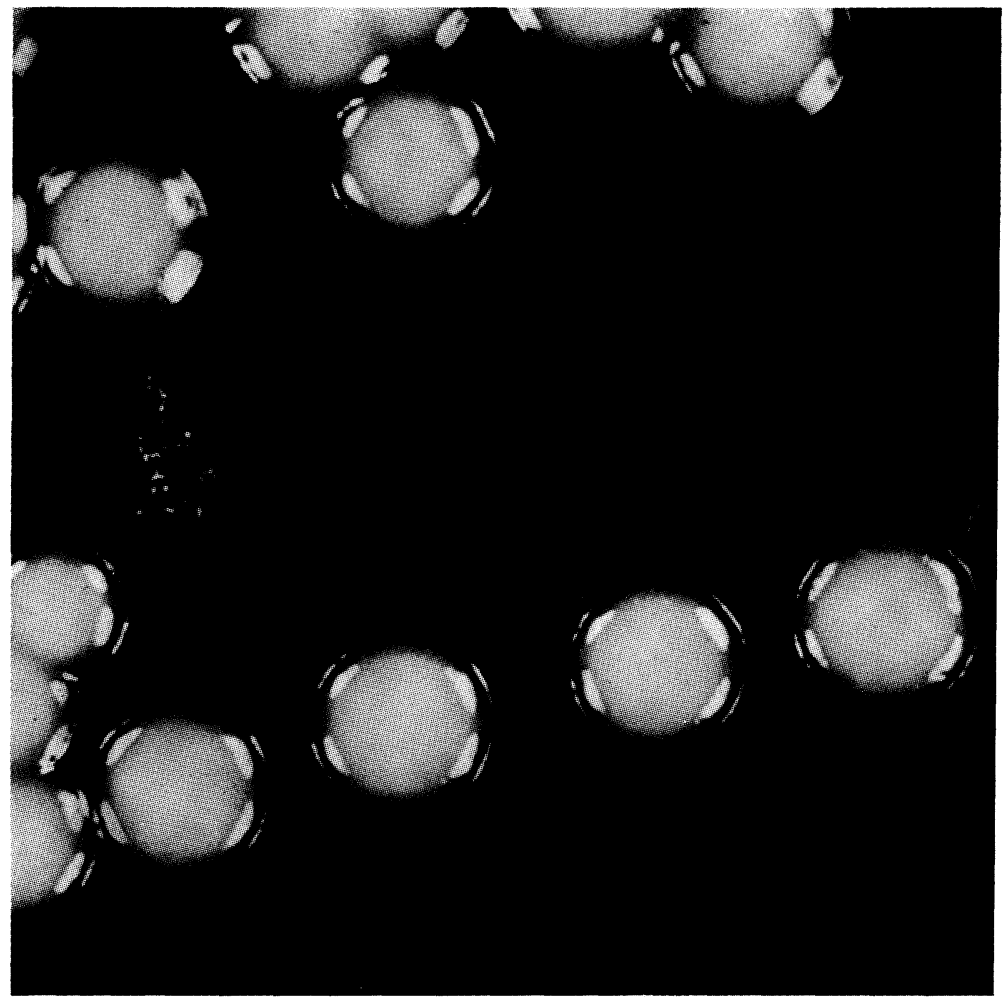

F i g. 7. Eighteen-hour surface colonies, grown at $37^{\circ} \mathrm{C}$. on 10 per cent horse-blood agar. Colony diameter between 3 and $5 \mathrm{~mm}$. 
Table 1. Control of Thermal Death Time.

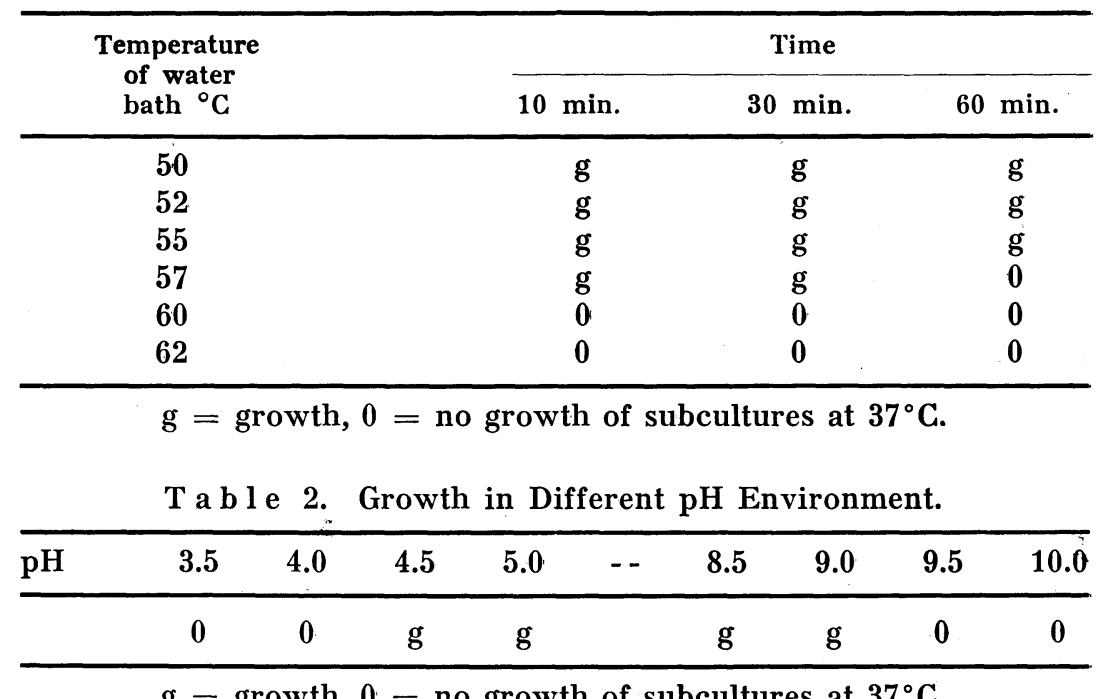

$\mathrm{g}=$ growth, $0=$ no growth of subcultures at $37^{\circ} \mathrm{C}$.

vely. Control of the subcultural growth was carried out on horseblood agar; the results are seen from Table 1.

$p H$. Control of growth in broth agar with different $\mathrm{pH}$ values gave the following result reported in Table 2.

Antibiotics. The sensitivity in vitro of the bacterial culture to different antibiotics was tested by an agar diffusion technique described by Ericsson and co-workers $(10,11)$. The microbe was then found to be in vitro

"sensitive"

"fairly sensitive"

"slightly sensitive"

"resistent" to chlortetracycline, polymyxin;

" sulfaisodimidin, streptomycin, oxytetracycline, tetracycline, neomycin;

" oleandomycin, erythromycin;

„, penicillin, chloramphenicol, bacitracin, novobiocin, nitrofurantoin;

Metabolic Properties.

The microbe is strictly aerobic. It grows abundantly at $37^{\circ} \mathrm{C}$. moderately at room temperature. After about 2 months' storage at $+4^{\circ} \mathrm{C}$. scanty growth was noticed.

Pigmentation was not proved after culture on potato slices and in Dorset's egg medium at $22^{\circ}$ and $37^{\circ} \mathrm{C}$., respectively. The culture was exposed to daylight for 6 weeks. 


\section{Biochemical Reactions.}

The figure after the respective biochemical reaction refers to the manual given in the bibliography, where the method used is described. Fermentation of Sugars (36).

The observations of the reactions in the different sugar media were made at $+4^{\circ},+20^{\circ}$ and $+37^{\circ} \mathrm{C}$. for 6 weeks.

Acid production in varying degrees without the formation of gas was shown at $20^{\circ}$ and $37^{\circ} \mathrm{C}$. in arabinose, xylose, dextrose, and galactose. Neither acid nor gas production was demonstrated in rhamnose, fructose, mannose, lactose, sucrose, trehalose, raffinose, starch, inulin, dextrin, glycogen, glycerol, adonitol, mannitol, sorbitol, dulcitol, inositol, salicin, amygdalin, arbutin.

In 10-per-cent lactose broth, acid production was obtained, however.

Litmus Milk shows slight acid production and coagulation within a week (34).

Indole Production not shown (19).

Methyl-Red Test negative (19).

Voges-Proskauer Test, modified by Barritt, negative (19).

Oxidase Test negative (34).

Nitrate Reduction negative. Neither nitrite (19) nor ammonia production (16) shown.

The microbe is urease-positive (19).

No Hydrogen Sulphide Production (19).

Methylene Blue Reduction strongly positive (38).

Growth in Methylene-Blue Milk (1:20.000, 1:10.000, 1:5.000, $1: 1.000$ ) : complete reduction in 1 day, coagulation in 1 week (38).

Liquid Ammonium-Citrate Medium: growth (19).

The microbe is catalase-positive (16) and does not liquify gelatin (16).

\section{Toxicity.}

After tests on mice, no toxin could be demonstrated in filtrates from cultures of $1,2,4$, and 6 days, resp., grown in meatbroth.

\section{Pathogenicity.}

Pathogenicity was tested on rabbits, guinea pigs, mink, férrets, and mice. The animals were inoculated with different amounts of 18 -hour meat-broth cultures incubated at $37^{\circ} \mathrm{C}$. and applied in different ways, see Table 3 . 
T a b l e 3. Pathogenicity to Laboratory Animals.

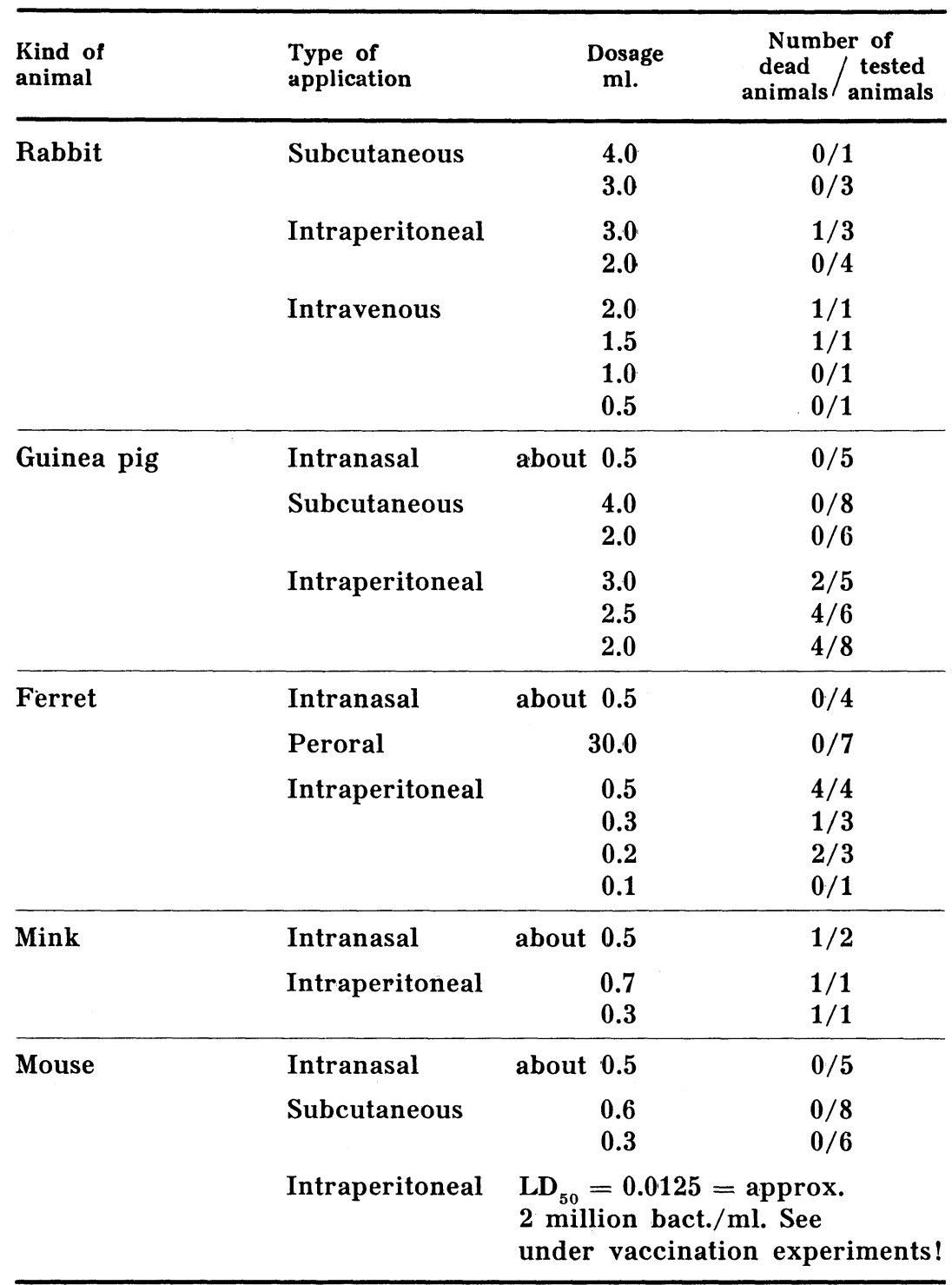

From the table it is seen that the microbe is pathogenic to mink after intraperitoneal and intranasal administration of broth culture. Death was caused by intraperitoneal or intravenous injections in rabbits. Ferrets, guinea pigs, and mice died only after intraperitoneal inoculation.

Four mink were placed at our disposal for experimental exa- 
mination. Two of them were injected intraperitoneally and died within 24 hours. At autopsy, signs of general infection with splenomegaly and general lymph-node reaction were found. The mesentery was hyperaemic and showed widespread haemorrhages. The abdominal cavity contained haemorrhagic, filamentous, mucous exudate. The lungs showed a few atelectatic and hyperaemic areas. The liver and kidneys were hyperaemic. Histological examination of the lungs showed foci of atelectasis and hyperaemia and escape of erythrocytes into the alveoli but no dilatation of the perivascular and peribronchial tissue spaces. Histologically, the brain was negative, disregarding hyperaemia of the meninges.

The remaining two mink were instilled intranasally. One of them died after 6 days. At autopsy splenomegaly and general lymph-node reaction were found. The lungs were enlarged, hyperaemic, and consolidated. The trachea and bronchi contained a haemorrhagic, filamentous, mucous exudate. Only small areas in the periphery of the lobes were emphysematous. Multiple

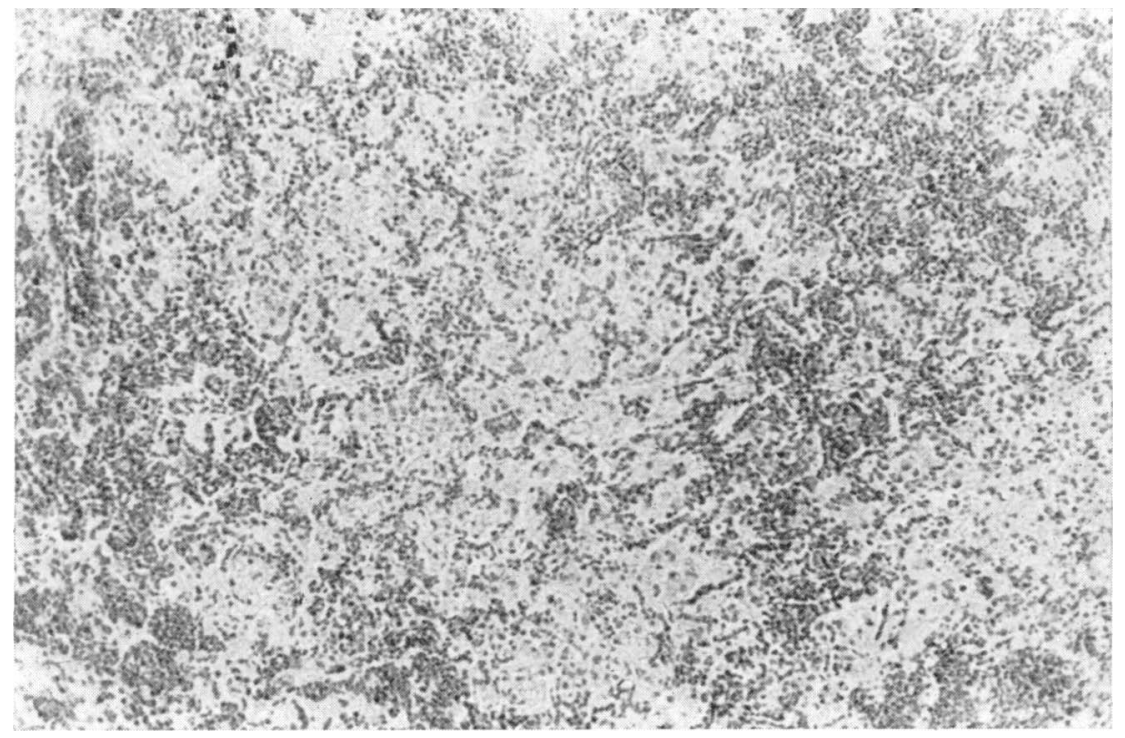

F i g. 8. 0 7121/59. Pneumonia in mink artificially produced through intranasal instillation of meat-broth culture of the isolated microbe. Pronounced hyperaemia of the pulmonary capillaries. The alveoli are filled with exudate fairly scarce in cells and containing ejected alveolar epithelial cells, phagocytes, here and there abundance of erythrocytes and considerable accumulations of bacteria. Leukocytes are very sparse. Haematoxylin-eosin, $130 \times$. 
petechiae were found in the pleura. Histological changes in the experiment mink resembled those seen in the naturally infected animals. (Fig. 8). Liver, kidneys, and myocardium were the sites of slight fatty changes. The spleen, the lymph-nodes of the body, the kidneys and the liver were infiltrated with plasma cells. In the renal tubules there were small cylinders of albumin. Except for hyperaemia in the meninges, the histological examination of the brain was negative. The remaining mink was killed 6 weeks later. At autopsy no morbid changes could be found macroscopically. Histological examination of the lungs revealed, however, slight interstitial infiltration of lymphohistiocytic cells and in a few small bronchi epithelial cells had been desquamated together with a small number of leukocytes.

The rest of the experiment animals, ferrets, rabbits, guinea pigs, and mice, died within a few days and at autopsy they showed spleen and lymph-node reactions without specific macroscopic or microscopic organic changes.

At bacteriologic examination, carried out on all the abovementioned animals, the internal organs revealed pure cultures of bacteria which corresponded biochemically and morphologically to the test cultures.

\section{Vaccination Experiments.}

Vaccination experiments were carried out on white mice of both sexes in a weight class between 16 and $18 \mathrm{~g}$.

Production of vaccine : 48-hour culture in 10-per-cent horse-serummeat-broth was centrifuged and the deposit suspended in saline solution to a concentration of 0.1 vol.per cent. Formalin to 0.2 per cent was added; inactivation for 3 days at $37^{\circ} \mathrm{C}$. Sterility and toxicity tests were carried out on mice.

Determination of the $\mathrm{LD}_{50}$ dose was done using 10 groups of 10 mice each. The $\mathrm{LD}_{50}$ was then determined to be $0.0125 \mathrm{ml}$. corresponding to approx. 2 million bacteria/ml.

An amount of $0.02 \mathrm{ml}$. of the vaccine, diluted to $0.3 \mathrm{ml}$. in a mixture of 25 per cent broth and 75 per cent saline was injected intraperitoneally into each of the mice in the different groups. Ten or 14 days later the mice were injected intraperitoneally with the test dose 20 or $30 \times 10^{6}$ bacteria in $0.5 \mathrm{ml}$. diluent. Corresponding doses were injected into the mice of the control groups. The mice were observed for 14 days after the test infection. The result is seen from Table 4 . 
T a b l e 4. Inoculation Experiments on White Mice.

\begin{tabular}{lccc}
\hline & \multicolumn{2}{c}{ Result } \\
\cline { 3 - 4 } $\begin{array}{l}\text { Test infection } \\
\text { dose }\end{array}$ & $\begin{array}{c}\text { Days after } \\
\text { vaccination }\end{array}$ & $\begin{array}{c}\text { Number of surviving animals/Number of } \\
\text { infected animals in }\end{array}$ \\
\cline { 3 - 4 } & 10 & $8 / 10$ & Control group \\
\hline $\begin{array}{l}\text { Approx. 20 million } \\
\text { bacteria }\end{array}$ & 14 & $8 / 20$ & $0 / 6$ \\
$\begin{array}{l}\text { Approx. 30 million } \\
\text { bacteria }\end{array}$ & 14 & & $0 / 6$ \\
\hline
\end{tabular}

about 20 million bacteria $=$ about $10 \mathrm{DL}_{50}$

It is seen from these orientating vaccination tests that the vaccine apparently has the ability to produce immunity in mice.

\section{DISCUSSION}

The pneumonia described was characterized by extensive dilatation of the adventitial spaces around the vessels and the bronchi with accumulation of exudate. In many cases the spaces had expanded and the walls of them had become necrotized to such an extent that the exudate had infiltrated the surrounding tissues. The exudate contained a large number of bacteria partly freely and partly phagocytized in macrophages. The slight occurrence of leukocytes was striking. Another characteristic was the injury to the vessels with the scattered but very profuse haemorrhages perivascularly, peribronchially, and into the alveoli.

The pneumonia produced by Hoyle and Orr (18) in mice after intranasal instillation, corresponds to the one described here. In their experiments these authors used several types of bacterial cultures of different virulence and found that, when bacterial material entered the lungs small atelectatic areas containing leukocytes and mononuclear cells were produced. The leukocyte reaction is dependent upon the virulence of the bacteria - the greater the virulence the more numerous the leukocytes. Surviving mice were killed at different intervals and examined. In cases of nonvirulent bacteria, a resolution was achieved, while in cases of greater virulence the infection seemed to extend mainly in two ways - centrifugally from the primary atelectatic areas, or along the vascular and bronchial adventitia. The lobar consolidation that appeared in the grave cases occurred 
through spread of the infection via the vascular adventitia to the surrounding alveoli. These belonged to lobuli which had not been affected primarily and which had unimpeded aeration from the bronchi. Hoyle and Orr termed this type of pneumonia angiogenous pneumonia.

A fully developed case of angiogenous pneumonia more seldom seems to occur, since other factors, e.g., septicaemia, cause death before the changes have reached any great extent. Early phases, on the contrary, are usual. An even distribution of bacteria and a small number of leukocytes are then seen in limited areas of the lungs.

The above-mentioned peribronchial and perivascular spaces have previously been considered lymph vessels. More thorough examinations of them have been made by Epstein (9), who inoculated mice intra-orally with Klebsiella cultures and obtained pneumonia in which similar adventitial changes were found along the arteries and arterioles but not along the veins or bronchi. By killing the mice at different intervals and performing serial sections of the lungs, he found that spaces in the adventitia were not connected with the lymph vessels.

The gross lesions seen in the mink examined by us resembled the changes seen in Pseudomonas aeruginosa and staphylococcal infections. These infections have been described as producing acute haemorrhagic purulent bronchopneumonia. The characteristic accumulations of exudate perivascularly and peribronchially with dilatation of the tissue spaces present in our mink do not seem to have been described previously in this species.

The microorganism was isolated both from the feed sample and from the mink carcasses. It was Neisserialike and corresponded morphologically and biochemically to Diplococcus $\mathbf{m u}$ cosus (v. Lingelsheim). The bacteriological nomenclature concerning this organism has not been quite determined. Seeliger (33) states that the Diplococcus mucosus described already in 1905 by $v$. Lingelsheim $(22,23,24)$ is synonymous to the Bacterium anitratum (B5W), reported by Schaub and Hauber (32) and by Stuart et al. (37). Schaub and Hauber have definitely distinguished this group from the genus Neisseria.

Ewing (12) and Aiken et al. (1) have emphasized relationship between, among others, Bacterium anitratum and the Mimeae group - especially the Herellea genus - described by De Bord in a number of publications $(5,6,7,8)$. According to these 
authors' opinion these closely related groups of bacteria do not belong to the Enterobacteriaceae but rather to the Achromobacteriaceae or the Pseudomonadaceae.

On the basis of fermentation reactions, De Bord (6) divides the tribus Mimeae into three genera, viz., Mima, Herellea, and Colloides and Skerman (35) has placed this tribus under Nonphotosyntetic organisms in his Key to the Genera of Bacteria. The tribus Mimeae has not been included in the seventh edition of Bergey's Manual (2). Our experimental results correspond to those described of the genus Herellea ${ }^{1}$ ).

As for penicillin and chloramphenicol the reaction of the bacterial culture isolated here corresponds closely to that by Brooke (3) and by Lünd (25) reported on a great number of $B$. anitratum cultures.

A survey of the literature with regard to the pathogenicity of these closely related organisms reveals that they have, on many occasions, been isolated from human cases of meningitis, eye infections, and also infections in the urinary and the respiratory systems. A case of lobar pneumonia has been described by Glick et al. (15). For a survey of the literature see Aiken et al. (1) and Rocha and Guze (31). The last-mentioned authors emphasize the possibilities of these organisms to cause diseases in humans but that the pathogenicity seems to be variable as welI in man as in laboratory animals. Deacon (4) has isolated 10 cultures of Herellea from human material, nine of which originate from cerebrospinal fluid from patients with head injuries and one culture from the urine of a patient operated on for a stricture of the urethra. As far as we know no spontaneous cases have previously been described in animals.

As has been mentioned, the same type of bacteria was found as pure cultures, from the feed sample as well as from the animal carcasses. Peroral administration of bacterial cultures was not experimentally performed in mink. On the other hand, two mink were instilled intranasally. In one of these, pneumonia was induced, the pathologico-anatomical pattern of which corresponded to that of the spontaneous cases. This fact speaks in favour of

1) We wish to thank Miss E. O. King, Laboratory Branch, Communicable Disease Center, Public Health Service, U. S. Department of Health, Education, and Welfare, Atlanta, Georgia for kindly conforming the identity of the type strain. 
the belief that the entrance of the infection might have been aerogenic.

There is no satisfactory explanation for the mortality and morbidity pattern of the original outbreak. A contributory cause of the lethal termination of the mink on the farm might have been low resistence for some reason or other. However, the owner had noticed no signs of disease or general weakness in any of the affected or unaffected animals. In one of the mink received, as well as in the one that died of pneumonia after being experimentally instilled intranasally, slight plasmacytosis was shown. This is a disease which seems to be to some extent associated with poor general condition. As many investigators have pointed out, another factor of importance in this connection is, the great variations in pathogenicity of the Herellea and Herellealike bacteria.

\section{REFERENCES}

1. Aiken, M. A., Ward, M. K. and King, E. O.: Off. Bull. Conf. of State and Publ. Hlth. Lab. Dir. 1956, 14, 126.

2. Breed, R. S., Murray, E. G. D. and Smith, N. R.: Bergey's Manual of Determinative Bacteriology. 7th ed. The Williams and Wilkins Co., Baltimore. 1957.

3. Brooke, M. S.: Acta path, microbiol. scand. 1959, 28, 338.

4. Deacon, W.: J. Bact. 1945, 49, 511.

5. De Bord, G. G.: J. Bact. 1939, 38, 119.

6. De Bord, G. G.: Iowa St. Coll. J. Sci. 1942, 16, 471.

7. De Bord, G. G.: J. Lab. clin. Med. 1943, 28, 710.

8. De Bord, G. G.: J. Bact. 1948, 55, 764.

9. Epstein, S.: J. Path. Bact. 1945, 57, 441.

10. Ericsson, H. and Svartz-Malmberg, G.: Antibiotica et Chemotherapia $1959,6,41$.

11. Ericsson, H.: Scand. J. clin. Lab. Invest. 1960, 12. Suppl. 50.

12. Ewing, W. H.: J. Bact. 1949, 57, 659.

13. Farrel, R. K., Leader, R. W. and Gorham, J. R.: Cornell Vet. 1958, $48,378$.

14. Garry-Andersson, A.-S.: Finsk VetTidskr. 1956, 62, 563.

15. Glick, L. M., Moran, G. P., Coleman, J. M. and O'Brien, G. F.: Amer. J. Med. 1959, 27, 183.

16. Hallmann, L.: Bakteriologie und Serologie. Dritte Aufl. Georg Thime Verlag, Stuttgart. 1961.

17. Hoff, H. and Woxholtt, C.: Nord. Vet.-Med. 1952, 4, 1201.

18. Hoyle, L. and Orr, J. W.: J. Path. Bact. 1945, 57, 441.

19. Kauffmann, $F .:$ Enterobacteriaceae. 2nd ed. Ejnar Munksgaard, Publisher, Copenhagen. 1954.

20. Knox, B.: Nord. Vet.-Med. 1953, 5, 731.

21. Kull, K.-E.: Personal communication. 
22. v. Lingelsheim, W.: Dtsch. med. Wschr. 1905, 31, 1217.

23. v. Lingelsheim, W.: Klin. Jb. 1906, 15, 373.

24. v. Lingelsheim, W.: Z. Hyg. InfektKr. 1908, 59, 457.

25. Lund, E.: Acta path. microbiol. scand. 1954, 34, 329.

26. Merchant, I. A. and Packer, R. A.: Veterinary Bacteriology and Virology. 5th ed. The Iowa State College Press, Ames, Iowa. 1956/58.

27. Momberg-Jørgensen, $H$. C.: Pelsdyrsygdomme. Page 82. A-S Carl Fr. Mortensen, København. 1952.

28. Momberg-Jørgensen, H. C.: Medlemsbl. danske Dyrlægeforen. 1953, $36,53$.

29. Momberg-J $\phi$ rgensen, $H$. C.: Nord. Vet.-Med. 1956, 8, 329.

30. Pridham, T. J. and Belcher, J.: Canad. J. comp. Med. 1958, 22, 99.

31. Rocha, H. and Guze, L. B.: Arch. intern. Med. 1957, 100, 272.

32. Schaub, I. G. and Hauber, F. D.: J. Bact. 1948, 56, 379.

33. Seeliger, H.: Zbl. Bakt. (Abt. 1). 1953, 159, 173.

34. Simmons, J. S. and Gentzkow, C. J.: Medical and Public Health Laboratory Methods. Lea and Febiger, Philadelphia. 1955.

35. Skerman, V.B. D.: A guide to the identification of the genera of bacteria. The Williams and Wilkins Co., Baltimore. 1959.

36. Society of American Bacteriologists: Manual of Microbiological Methods. McGraw-Hill Book Co., Inc. New York, Toronto, London. 1957.

37. Stuart, C. A., Formal, S. and McGann, V.: J. infect. Dis. 1949, 84, 235.

38. Wilson, G. S. and Miles, A. A.: Topley and Wilson's Principles of Bacteriology and Immunity. 4th ed. Edward Arnold (Publishers) Ltd., London. 1955.

39. Winkle, S.: Mikrobiologische und Serologische Diagnostik. Zweite Aufl. Gustav Fischer Verlag, Stuttgart. 1955.

\section{SUMMARY}

The authors report an outbreak of lethal haemorrhagic pneumonia in mink.

Pure cultures of bacteria of the genus Herellea (De Bord) were isolated from the various organs as well as from a feed sample. The pathological changes could be reproduced experimentally in mink. In animals, spontaneous outbreaks of disease caused by this bacterial species, have not previously been described.

\section{ZUSAMMENFASSUNG}

Hämorrhagische Pneumonie bei Nerzen auf Grund einer Infektion Herellea (Syn. Diplococcus mucosus, B5W, Bacterium anitratum).

Die Verfasser berichten über einen Ausbruch lethal verlaufenden hämorrhagischen Pneumonie in einem Nerzbestand. Von sowohl Tierkadavern als auch Futterproben wurden Reinkulturen von Herellea Bakterien (De Bord) isoliert. Die Pathologisch-anatomischen Ver- 
änderungen liessen sich auch im Tierversuch an Nerzen reproduzieren. Durch diese Bakterien verursachte Krankheitsausbrüche bei Tieren sind $u$. W. bisher nicht beschrieben worden.

\section{SAMMANFATTNING}

Hemorrhagisk pneumoni hos mink, orsakad av Herellea (syn. Diplococcus mucosus, B5W, Bacterium anitratum).

Författarna rapportera ett utbrott av letalt förlöpande hemorrhagisk pneumoni i en minkbesättning. Från såväl djurkadaver som foderprov isolerades renkulturer av bakterier tillhörande genus Herellea (De Bord) och de sjukliga förändringarna ha experimentellt kunnat reproduceras på försöksmink. Spontana sjukdomsutbrott hos djur orsakade av denna bakterietyp ha tidigare ej redovisats.

(Received May 23. 1961). 